\title{
КРИМІНАЛІСТИЧНА КЛАСИФІКАЦІЯ ЗЛОЧИННИХ УГРУПОВАНЬ ПАРАМІЛІТАРНОГО ТИПУ
}

Мартиненок Д. О.

у статmі проаналізовано особливості здійснення класифікаційних досліджень під час наукового пізнання. Визначено сутність класифікації як інструменту наукового пізнання. Обґрунтовано значення класифікаційних досліджень для розроблення методик розслідування злочинів різних категорій. Досліджено основні наукові підходи щодо використання класифікацій у криміналістиці. Особливу увагу звернено на необхідність використання класифікаційних досліджень під час розроблення міжвидових методик розслідування злочинів. Визначено, що в межах криміналістики наявна значна кількість класифікацій злочинних угруповань загальнокримінальної спрямованості. Наголошено, що криміналістична класифікація злочинних угруповань парамілітарного типу наразі в межах криміналістики не здійснювалась. Обґрунтовано систему класифікаційних критеріїв, які можуть бути використаними для розроблення криміналістичних класифікацій злочинних угруповань парамілітарного типу. Розроблено криміналістичну класифікацію злочинних угруповань парамілітарного типу за такими критеріями: обстановка формування злочинного угруповання; територіальна поширеність діяльності злочинного угруповання; розгалуженість структури злочинного угруповання; за кількістю і типами лідерства у злочинному угрупованні; за базовими формами злочинної діяльності угруповання; наявністю інфраструктури для забезпечення злочинної діяльності. Охарактеризовано передумови виникнення та становлення окремих типів лідерства в злочинних угрупованнях парамілітарного типу. Визначено чинники, які впливають на вибір форм базової злочинної діяльності таких угруповань. Обґрунтовано, що вибір базової форми злочинної діяльності не відбувається спонтанно, а залежить від певних чинників та умов, зокрема: а) криміногенності території, на якій вчиняються злочини; б) рівня контролю за цими територіями з боку правоохоронної системи; в) соціально-економічних характеристик регіону; г) рівня озброєності та військової підготовки учасників парамілітарного злочинного угруповання; д) наявності інфраструктури для здійснення конкретного виду злочинної діяльності, наприклад, приміщень для тривалого утримання заручників та здійснення контролю над ними.

Ключові слова: розслідування, криміналістична класифікація, злочинні угруповання парамілітарного тuny, класифікаційні критерії, методика розслідування.
Martynenok D. O. Forensic classification of criminal groups of paramilitary type

Thearticleanalysesthepeculiaritiesoftheimplementation of classification research during scientific cognition. The essence of classification as a tool of scientific knowledge is determined. The significance of classification researches for development of methods of investigation of crimes of different categories is substantiated. The main scientific approaches to the use of classifications in criminology are studied. Particular attention is paid to the need to use classification studies in the development of interspecific methods of crime investigation. It is determined that within criminology there is a significant number of classifications of criminal groups of general criminal orientation. It is emphasized that the criminological classification of criminal groups of the paramilitary type has not been carried out within criminology so far. The system of classification criteria which can be used for development of criminological classifications of criminal groups of paramilitary type is substantiated. A forensic classification of criminal groups of the paramilitary type according to the following criteria has been developed: the situation of formation of a criminal group; territorial prevalence of criminal group activity; branching structure of the criminal group; by the number and types of leadership in a criminal group; basic forms of criminal activity of the group; the availability of infrastructure to support criminal activity. The preconditions for the emergence and formation of certain types of leadership in criminal groups of the paramilitary type are described. The factors influencing the choice of forms of basic criminal activity of such groups are determined. It is substantiated that the choice of the basic form of criminal activity does not occur spontaneously, but depends on certain factors and conditions, in particular: a) criminogenic of the territory where crimes are committed; b) the level of control over these territories by the law enforcement system; c) socio-economic characteristics of the region; d) the level of armament and military training of members of the paramilitary criminal group; e) the availability of infrastructure to carry out a specific type of criminal activity, such as facilities for the long-term detention and control of hostages.

Key words: investigation, forensic classification, paramilitary-type criminal groups, classification criteria, methods of investigation.

() Мартиненок Д. О., 2020 
Постановка проблеми та іï актуальність. У межах криміналістичної науки одним з інструментів здійснення наукового дослідження $\epsilon$ класифікація об'єктів, які пізнаються дослідником. Як відзначається в загальнонаукових джерелах, побудова класифікації та типології досліджуваних об'єктів і явищ характерна для будь-якої галузі наукового знання. У загальнонаукових джерелах відзначається, що одним із засобів пізнання різних явищ і процесів уважається їх наукова класифікація. Класифікувати означає розподілити предмети, явища або поняття на класи, групи тощо за спільними ознаками, властивостями. Класифікація - це система розподілу предметів, явищ або понять на класи, групи тощо за спільними ознаками та властивостями [4, с. 673].

Не $\epsilon$ виключенням із цього правила і криміналістика як відповідна самостійна система наукового знання, адже формування відповідних методик розслідування неможливе без розроблення ґрунтовних класифікацій тих об'єктів, які покладено в основу розроблення тієї чи іншої методики розслідування злочинів. Учені-криміналісти наголошують, що на початку процесу формування конкретної методики розслідування необхідно вибрати й надати характеристику предмета (підстави формування) методики розслідування вид або групу злочинів. Даний предмет-підстава завжди має спиратися на обґрунтовану та практично значиму класифікацію злочинів [5, с. 148]. Водночас необхідно звернути увагу, що в межах криміналістичної науки об'єктами, які досліджуються з використанням класифікаційних методів, $\epsilon$ не лише злочини. А.Ю. Головін відзначає, що в криміналістиці наявні широкі можливості для класифікаційних досліджень. Об'єктами класифікації в ній $\epsilon$ широке коло явищ, які характерні для процесу розкриття та розслідування злочинів. Поряд із цим у сучасній криміналістиці склалась ситуація, коли за недостатньої розробленості теоретичних основ криміналістичної класифікації здійснюються класифікації в окремих їі областях. Продовжуючи, дослідник відзначає, що особливостями криміналістичної класифікації можна виділити:

об'єкт класифікації - поняття як думку, яка відображає ознаки якогось предмета чи явища, що входить до предмету вивчення криміналістичної науки;

процедуру класифікації - класифікація завжди здійснюється за певним критерієм, тобто ознакою, яка розрізняє групи об'єктів у множинні [6, c. 64].
Як відзначає професор В.В. Тіщенко, класифікацію можна розглядати як процес і результат застосування типологічного методу, що дозволяє розділити множинність об'єктів на підмножини (підкласи) за визначеними ознаками. Наукова класифікація допомагає розкрити сутність досліджуваних об'єктів, повніше і точніше виділити й оцінити їхні властивості, зв'язки і відносини, сприяє систематизації знань, понятійного апарату, служить базою для подальшої розробки теорій і положень у тій чи іншій науковій галузі [11, с. 28].

Так, у разі формування міжвидових та позавидових методик розслідування об'єктами криміналістичної класифікації можуть виступати особа злочинця, особа потерпілого, обстановка вчинення злочину, способи злочинної діяльності тощо. На нашу думку, в межах криміналістичної науки самостійним об'єктом класифікаційних досліджень можуть виступати і злочинні угруповання парамілітарного типу. Безумовно, у криміналістиці та теорії оперативно-розшукової діяльності розроблено значну кількість класифікацій злочинних угруповань за різноманітними критеріями: а) особливостями структурної побудови; б) типами лідерства в таких злочинних угрупованнях; в) формами базової злочинної діяльності відповідних злочинних угруповань; д) рівнем та інтенсивністю корупційних зв'язків та інших елементів інфраструктури злочинної діяльності.

На нашу думку, класифікація злочинних угруповань парамілітарного типу $\epsilon$ ключовим завданням для формування відповідної методики розслідування, оскільки на їі основі: розробляється система типових слідчих ситуацій; обґрунтовується система версій, які висуваються слідчим; розробляється система і тактичні прийоми проведення окремих слідчих (розшукових) та негласних слідчих (розшукових) дій; розробляються типові прийоми нейтралізації протидії розслідуванню тощо.

Водночас необхідно наголосити, що в межах криміналістичної науки класифікація злочинних угруповань парамілітарного типу не розроблялась.

Аналіз останніх досліджень i публікацій. У різні часи класифікаційні дослідження злочинних угруповань у межах розроблення криміналістичних методик розслідування, а також теорії оперативно-розшукової діяльності здійснювали різні науковці, зокрема: Ю.П. Аленін, Л.І. Аркуша, В.П. Бахін, Р.С. Бєлкін, В.Д. Берназ, А.Ф. Волобуєв, В.А. Журавель, А.В. Іщенко, 
Н.І. Клименко, В.О. Коновалова, І.М. Лузгін, В.В. Лисенко, Г.А. Матусовський, В.О. Образцов, М.В. Салтевський, М.О. Селіванов, Р.Л. Степанюк, В.В. Тіщенко, Ю.М. Чорноус, В.М. Шевчук, В.Ю. Шепітько, Б.В. Щур, М.П. Яблоков та інші вчені.

Мета статті - розроблення криміналістичної класифікації злочинних угруповань парамілітарного типу.

Виклад основного матеріалу. Безумовно, що, розробляючи таку криміналістичну класифікацію, перш за все необхідно виокремити відповідні класифікаційні критерії, які найбільш детально дозволяють класифікувати відповідний об'єкт та розкрити його особливості. Так, на нашу думку, такими класифікаційними критеріями можуть бути: по-перше, обстановка формування злочинного угруповання; по-друге, територіальна поширеність злочинної діяльності; no-mpeme, розгалуженість структури злочинного угруповання; по-четверте, кількість і тип лідерства в злочинному угрупованні; no-n'яте, базові форми злочинної діяльності угруповання; по-шоcme, наявність та особливості інфраструктури, яка забезпечує функціонування угруповання; по-сьоме, інтенсивність зв'язків угруповання зі злочинними угрупованнями загальнокримінальної спрямованості.

Аналізуючи такий критерій, як обстановка формування злочинного угруповання, зауважимо, що під такою обстановкою ми розуміємо конкретні параметри адміністративно-територіальної одиниці, соціально-економічні та політичні умови об'єктивної дійсності, в яких формувалось конкретне злочинне угруповання парамілітарного типу. На нашу думку, за вказаним критерієм можна виокремити такі злочинні угруповання парамілітарного типу:

а) сформовані під час активних військових дій на території військового конфлікту;

б) сформовані під час «замороженого» військового конфлікту;

в) сформовані під час протестних акцій різного типу поза межами території військового конфлікту;

г) сформовані в межах територій, на яких збройний конфлікт відсутній.

Щодо територіальної поширеності діяльності злочинних угруповань парамілітарного типу можна виокремити такі їх різновиди:

а) угруповання, які здійснюють злочинну діяльність виключно в межах периметру ведення бойових дій. Необхідно звернути увагу, що мотивація на вчинення такими угрупованнями злочинної діяльності зумовлюється самими особливостями обстановки військових дій, зокрема: а) можливістю безперешкодного проникнення до приміщень та інших об'єктів, які належать громадянам, під приводом виконання бойових завдань; б) незаконним вилученням у громадян їхньої власності під приводом потреби іï використання у військових цілях тощо.

б) угруповання, які здійснюють злочинну діяльність поза межами зони військових дій;

в) угруповання, злочинна діяльність яких має міждержавний характер.

Продовжуючи, відзначимо, що за критерієм розгалуженості структури злочинного угруповання, на нашу думку, доцільно виокремити:

а) злочинні угруповання з незначною кількістю учасників, які переважно локалізуються в межах периметру конкретної адміністративної одиниці;

б) злочинні угруповання, які формують та координують свої осередки в різних регіонах держави.

Класифікуючи злочинні угруповання за кількістю та типами лідерства, на нашу думку, можна виокремити такі їх види:

а) злочинні угруповання з ідейним лідером, який не бере безпосередньої участі в злочинній діяльності групи, але виступає морально-ідеологічним авторитетом, система цінностей якого консолідує внутрішні зв' язки злочинного угруповання. Як відзначають дослідники, найбільш далеким від реальної злочинної діяльності угруповання, як правило, є лідер-натхненник, який може виконувати функції лише технічного чи кримінального радника, юридичного консультанта, який застерігає злочинне угруповання від небезпечних для його існування кроків, психологічно сильної особистості, яка здатна зміцнити рішучість інших членів злочинного угруповання парамілітарного типу. Такий тип лідерства характерний для перших етапів існування злочинних угруповань. У цей період він може виконувати й інші лідерські функції, навіть виконувати лідируючу роль під час вчинення окремих злочинів. Водночас із часом, коли група укріпляється, він відходить від конкретної злочинної діяльності й бере на себе адміністративні функції [1]. Інші вчені відзначають, що категоріям осіб, які є лідерами/організаторами злочинної діяльності на території проведення АТО, здебільшого притаманні такі риси: особи у віці від 35 до 45 років і старші; мають значний злочинний досвід i «авторитет» серед злочинного елементу, відповідний рівень кваліфікації та злочинну спеціалізацію (крадіжки, грабежі, розбої 
тощо); неодружені - 52\% або розлучені - 43\%; здійснюють роль організаторів та консультантів організованих злочинних груп, надаючи інформацію про можливі місця вчинення злочинів (розбоїв, крадіжок із приміщень тощо), навчаючи безпосередніх учасників злочину прийомам і методам його вчинення; матеріально забезпечені; мають зв'язки з місцевими органами виконавчої влади; отримують більшу частину доходів від злочинної діяльності та вирішують питання щодо організації незаконної винагороди особам, зокрема й корумпованим працівникам правоохоронних органів та виконавчої влади, з метою забезпечення «прикриття» злочинної діяльності [2].

б) злочинні угруповання, які координуються та керуються групою лідерів із рівним статусом та впливом на структуру злочинної діяльності угруповання;

в) угруповання із ситуативним лідерством. Необхідно відзначити, що така модель характерна для злочинних угруповань парамілітарного типу на початковому етапі їх формування, коли декілька членів групи користуються однаковим рівнем авторитету і можуть виконувати керівну функцію в залежності від задачі, яка вирішується злочинним угрупованням у процесі діяльності. До таких типових задач можна віднести: по-перше, ведення переговорів із представниками органів державної влади та правоохоронною системою; по-друге, представництво інтересів угруповання в засобах масової інформації; no-mpemє, планування злочинної діяльності; по-четверте, координацію такої діяльності в момент учинення конкретних злочинів; no-n'яте, встановлення корупційних зв'язків із представниками органів державної влади та місцевого самоврядування.

Бажаність і перевага того чи іншого типу лідерства залежать від ситуації та завдань, що стоять перед групою. Водночас, незважаючи на те велике значення, що його має лідер, впливаючи на групову атмосферу, він не зможе зберегти свої позиції, якщо ситуація в групі й соціально-психологічний настрій їі членів вимагають іншого «стилю лідерства» [8, с. 348]. Методи ж і засоби, якими користується лідер для досягнення успіху, тісно узгоджуються з конкретною ситуацією й складом групи, із соціальною та психологічною сумісністю лідера з іншими членами групи. Крім того, тип лідера пов'язується із психічним типом людини, умовами їі життя, зі ступенем їі виучки, натренованістю, із завданнями, які він перед собою ставить, тощо [10].
Виокремлюючи як класифікаційний критерій базові форми злочинної діяльності, необхідно звернути увагу на зміст цієї категорії. Так, науковці відзначають, що стосовно розуміння організованої злочинності можна виділити три основні підходи, що мають місце в сучасній кримінологічній думці, одним з яких $є$ предметний - через визначення кола злочинів, учинення яких притаманне саме організованій злочинності [9]. На нашу думку, базова форма злочинної діяльності - це система однотипних дій, на вчинення яких зорієнтоване злочинне угруповання. Аналіз матеріалів практики свідчить, що для злочинних угруповань різного типу визначення базової форми злочинної діяльності відбувається через певний період після початку функціонування угруповання. Крім того, вибір базової форми злочинної діяльності не відбувається спонтанно, а залежить від певних чинників та умов, зокрема: а) криміногенності території, на якій вчиняються злочини; б) рівня контролю за цими територіями з боку правоохоронної системи; в) соціально-економічних характеристик регіону; г) рівня озброєності та військової підготовки учасників парамілітарного злочинного угруповання; д) наявності інфраструктури для здійснення конкретного виду злочинної діяльності, наприклад, приміщень для тривалого утримання заручників та здійснення контролю над ними.

Опрацювання матеріалів практики свідчить, що для більшості злочинних угруповань парамілітарного типу на початкових стадіях їхньої злочинної діяльності базовою формою $\epsilon$ вчинення злочинів проти власності. Наведене зумовлюється наявністю на території ведення бойових дій значної кількості майна, яке належним чином не охороняється, та до якого є вільний доступ. Крім того, мотиваційним елементом вчинення таких злочинів у зоні бойових дій $є$ мінімальний ризик притягнення до кримінальної відповідальності через латентний характер злочинної діяльності, оскільки потерпілі не мають змоги звернутись до правоохоронних органів із відповідними повідомленнями про вчинення злочину.

Як свідчить проведене дослідження, вибір подальших форм злочинної діяльності як базових, які характеризуються більш складними формами, корелює із встановленням злочинними угрупованнями парамілітарного типу контролю за відповідними територіями чи населеними пунктами і виконання ними функцій із підтримання правопорядку на відповідних територіях, зокрема й виконання функцій, які характерні для органів 
державної влади. Таким чином, проаналізувавши наукові джерела та матеріали практики, можна виокремити такі форми базової злочинної діяльності злочинних угруповань парамілітарного типу:

а) угруповання, які вчиняють ситуативні злочини проти власності, виходячи з конкретних обставин. Зазвичай учинення таких злочинів зумовлюється потребою в забезпеченні групи речами першої необхідності у випадку їх функціонування поза межами державних збройних утворень та правоохоронних структур i, як наслідок, відсутністю матеріального забезпечення з боку держави.

б) угруповання, котрі вчиняють злочини корисливо-насильницької спрямованості, які ретельно плануються, зокрема в контексті вибору об'єкта злочинного посягання та оцінки можливості притягнення до кримінальної відповідальності;

в) злочинні угруповання, які здійснюють контроль за функціонуванням нелегальних та кримінальних ринків;

г) злочинні угруповання, основною формою діяльності яких $\epsilon$ участь у масових заворушеннях та дезорганізації роботи органів державної влади. Як відзначає Б.Ш. Бейбулатов, організацію незаконного воєнізованого формування нерідко в первинному варіанті здійснюють з незлочинною метою. В уявленні певної групи осіб зазначена мета може бути суспільно корисною. Формування можуть створювати з метою захисту населення від можливих бойових або інших провокаційних виявів екстремістські налаштованих груп [3]. Однак навіть якщо не передбачене законом воєнізоване або збройне формування і створюють із суспільно корисною метою, то брак необхідного контролю з боку держави дає йому змогу досить легко трансформуватися в об'єднання зі злочинною метою. Причому в такий спосіб можна створювати «кишенькові воєнізовані громадські формування», які легко можуть перетворитися на «приватні збройні сили» [7].

Аналізуючи наступний критерій, зокрема наявність інфраструктури, яка забезпечує функціонування злочинного угруповання, відзначимо, що ми солідаризуємось із позицією Д.М. Цехана, який відзначає, що інфраструктура злочинності це система суб'єктів і засобів, що не володіють чіткими криміногенними ознаками, проте забезпечують злочинну діяльність, а також виступають інструментом взаємодії між злочинністю і соціально-економічними інститутами [12].

Використовуючи як класифікаційний критерій наявність інфраструктури злочинної діяльності, угруповання парамілітарного типу можемо класифікувати на такі види:

а) угруповання, в яких відсутня інфраструктура забезпечення злочинної діяльності. Як правило, така ситуація характерна для парамілітарних злочинних угруповань із простими формами злочинної діяльності, які часто змінюють місце дислокації, що не дає можливості створити стійку інфраструктуру злочинної діяльності на відповідній території;

б) угруповання зі сформованою інфраструктурою для вчинення злочинів, зокрема наявністю приміщень для зберігання зброї, утримання заручників та майна, отриманого в результаті злочинної діяльності;

в) угруповання парамілітарного типу з розвинутою інфраструктурою для відтворення кадрового потенціалу угруповання. Такими інфраструктурними елементами $\epsilon$ клуби, молодіжні об'єднання, які пропагують окремі типи ідеологій, тренувальні центри, які забезпечують військову й тактичну підготовку осіб, які не брали участь у бойових діях;

г) угруповання зі сформованою інфраструктурою для забезпечення протидії кримінальному переслідуванню. До таких інфраструктурних елементів можуть бути віднесенні політичні партії, громадські організації, засоби масової інформації, система корупційних зв'язків у правоохоронних органах.

Висновки. Підсумовуючи, можна відзначити, що формування криміналістичної класифікації злочинних угруповань парамілітарного типу $\epsilon$ невід'ємним елементом формування міжвидової криміналістичної методики розслідування їхньої злочинної діяльності. Наведена теза зумовлюється тим, що формування методики розслідування злочинної діяльності угруповань парамілітарного типу передбачає побудову декількох рівнів криміналістичної методики, в тому числі базуючись на розробленій вище класифікації.

\section{Література}

1. Анисимов Е.Б. О криминалистической характеристике руководителя преступной организации. Известия Алтайского государственного университета. Барнаул, 2009. № 2. С. 77-81.

2. Анциферов 0.Ю. Оперативно-розшукова протидія підрозділами карного розшуку злочинам проти власності у районі проведення антитерористичної операції : автореф. дис. ... на здобуття наук. ступеня канд. юрид. наук : 12.00.09. Харків, 2015. 20 c. 
3. Бейбулатов Б.Ш. Уголовно-правовые и криминологические аспекты организации и участия в незаконных вооруженных формированиях : дисс. ... канд. юрид. наук : 12.00.08. Ставрополь, 2001. 190 с.

4. Великий тлумачний словник сучасної української мови / укладач і головний редактор Т.В. Бусел. Київ : Ірпінь ВТФ «Перун», 2009. 1736 с.

5. Гармаев Ю.П., Лубин А.Ф. Проблемы создания криминалистических методик расследования преступлений. Теория и практика. Санкт-Петербург, 2006. 303 c.

6. Головин А.Ю. Криминалистическая систематика : монография. Москва : ЛексЭст, 2002. 335 с.

7. Конончук А.О. Мета створення непередбачених законом воєнізованих або збройних формувань та участі в них. Науковий вісник Начіональної академії внутрішніх справ. 2018. № 3. С. 288-302.

8. Краткий психологический словарь / под ред. А.В. Петровского и М.Г. Ярошевского. Москва : Политиздат, 1985. С. 343.
9. Міняйло Н. Співвідношення понять групової та організованої злочинності. Науковий часопис Національної академії прокуратури України. 2016. № 2. C. 66-73.

10. Сороковой А.Г. Социально-психологические основы руководства. Москва, 1971. C. 125-126.

11. Тіщенко В.В. Теоретичні і практичні основи методики розслідування злочинів : монографія. Одеса : Фенікс, 2007. 260 с.

12. Цехан Д.М. Інфраструктура злочинності: теоретичний аналіз. Вісник Київського Національного університету імені Тараса Шевченка. 2015. № 2. C. 53-56.

Мартиненок Д. О., аспірант кафедри кримінального процесу Одеського державного університету внутрішніх справ 